\title{
Strengthening Democracy for Women in Brebes
}

\author{
Muhammad Japar*, Dini Nur Fadhillah \\ Faculty of Social Science \\ Universitas Negeri Jakarta \\ Jakarta, Indonesia \\ *mjapar@unj.ac.id
}

\begin{abstract}
NGO movements in Indonesia as well as other developing countries, initially left to the left, then take on the position of movement at the local level to improve the welfare of their communities. Simultaneously, populist movements supported by the World Bank that support neo-liberal projects also develop various political strategies that move at the local level. They move along with the momentum of political decentralization in Indonesia, by carrying the values of good governance. This study shows how women's organizations participate in strengthening democracy in Brebes. This research uses qualitative descriptive method. Data obtained through observation of PEKKA organization activities (Women Headed Family Empowerment) in Brebes, Central Java. Interviews were conducted with PEKKA leaders, administrators and members. The results of this study indicate that strengthening democracy for women in rural areas increases women's active participation in conveying aspirations without discrimination in Brebes and increasing the potential of women to be involved in decisionmaking in village consultations in Brebes.
\end{abstract}

Keywords-brebes; democracy; women

\section{INTRODUCTION}

Democracy has been applied by some people in the archipelago is far away before interacting with the western nation. Growing democratization process at various dimensions of national and state life, is a breath of fresh air for women. Law enforcement efforts, civil society empowerment, and spreading attention to human rights, has raised public awareness to erode racial, ethnic, national, religious, gender and minority discrimination there is. The reform process is a vast gateway to doing many things to be sustaining the journey of democratization in various sectors of life. The growth of democratic discourse that gives space to the public society without distinction of race, race, class and sex. Room, access, and opportunity given to women to take part in the era of globalization, because the participation of women in various sectors becomes an inevitability building gender sensitivity into an urgent need. All this time women are still impressed as subordinate, marginal, slow to actualize yourself well. Though many things can be done women for the benefit of the ummah, part of the democratization process on earth. Unity has the meaning that the melting of each element with a character that vary, remain united in diversity, understand each other, behave and think positively of the differences. The example of democracy is based on Daskalopoulou satisfaction with democracy and social capital in Greece [1]. And organizational democracy, ethics and leadership can provide insight into furthering organizational democratization [2].

Since December 2013, rural autonomy is politically acknowledged by the State with the adoption of Law 6/2014 on rural. The rural currently has an executive and legislative body of rural governance and a rural consultative body with a proportional role and support for financing. While the judicial section follows the existing judicial system as well as the institutional and institutional institutions that hold the federative power of the rural deliberations as the highest consultative forum and the form of popular democracy through deliberative rurals. The rural legislation can make rural regulations, arrange budgets, manage assets and develop a Rural Owned Enterprise. The concept of participatory development is wide open through the mechanism of rural consultation, as it will gradually be supported by 2015 financing by $40 \%, 2016$ by $60 \%$ and 2017 by $100 \%$ of the total rural funds promised by rural law with an average of Rp 1, 4 Billion [3]. For that purpose the focus of this research is the activity of Women Headed Family Empowerment Organization (PEKKA) in providing democracy education for women in the rural area of Prohibition. PEKKA has a vision for empowerment of female heads of household in order to build a prosperous, just gender, and dignified society. PEKKA is an initiative to empower women heads of households, which was initiated in late 2000 from early plans of KOMNAS WOMAN who want to document the widows' lives in conflict areas and the World Bank's desire through the Region Development Program (PPK) to respond to the request of widows of conflict victims in Aceh to gain access resources in order to overcome their economic and traumatic problems. Initially this effort was given the name "Widows Project" which is fully supported by grants from Japan Social Development Fund (JSDF) through World Bank Trust Fund. KOMNAS WOMAN then cooperated with Women Resources Development Center (PPSW), formed National Secretary (Seknas) PEKKA to develop this initial idea. "Widows Project" in transformation into PEKKA by Nani Zulminarni who became National Coordinator (Kornas). This transformation is expected to make PEKKA more provocative and ideological, by placing a widow on the position, role, and responsibilities of the head of the family and not from marital status alone. In addition, this effort is expected to also make social change by raising the dignity of the widow in society that has been had negative Stereotype (labeling). Title of Women Headed Family Empowerment Program or abbreviated PEKKA Program, and 
PEKKA is then established and agreed to become the name of the institution implementing this new initiative. Furthermore, the word PEKKA is also used to briefly mention. The focus of this research is to make rural women confidence in opinion, increase women's participation in the rural area, develop critical awareness of rural women, control rural women in rural government decision making and balancing citizens rights the rural of Larangan, Brebes, Central Java. During 2015 Pekka Union expanded its membership in West Sulawesi Province and to 13 new districts, in South Sumatera, Central Java, South Sulawesi, West Sulawesi each expanding one district, 2 districts in Southeast Sulawesi province, and 3 regencies / municipalities in the province West Kalimantan and Bali. Thus until the end of 2015 Pekka Union has spread in 20 Provinces, 65 Regencies, 229 Districts and 855 villages.

In Georgia has a two level administrative structure of governance there are central and local governments. The general meeting of the settlement is the form of government participation in the governance of the city or rural. Sakrebulo is the one of the rural area in Georgia. Women's employment in there is only $9 \%$. In general, women are more passive in the decision making process on the community level [4]. While in rural areas, there are still women who experience disenchantment in democracy. Rural women are integrated into the rural economy, which is basically labor intensive and which exerts a heavy physical charge on the majority of women and children [5].

The government of Indonesia is committed to upholding women 's provisions and is signatory to several commitments and covenants about gender equality. Indonesia is committed to the principle of gender equality through a variety of national and international commitments.

In the Law 10/2008 on General Election to ensure that at least 30 percent of women are nominated on the list of parliamentary candidates to address the gender deficit in the politics of the country. The presence of Organizations that have the spirit of development for the empowerment of women, especially female heads of family is very helpful for the advancement of women in Indonesia.

\section{THEORETICAL}

According to Muneera Alshurman democracy is defined as the existence of government that has been chosen by people. And democratic education plays a vital role in creating awareness about democracy therefore it should be open for all citizens of a democracy society [6]. Democratic participation requires a clear theory of the democratic outline. In a democratic life there are no other things besides regular election, the centre of the activities of the natural community, the private world of civil society and the area of their actions will depend heavily on the resources they have. According to David Held in democratic autonomy people or society should enjoy equal rights and subsequently equal obligations in the specification of the political framework that creates and limits the opportunities provided by society.

According to Chrysanthi Charatsari and Afroditi In general the stories from data indicate the progress regarding women's position within family and society was slow an erratic whereas it is still underway since gender role appropriateness remains a robust construction [7]. And the analysis proved that the first signs of change appeared in the 1970s when the migration from and rural development give opportunities for political participation. The greater self-confidence, inner strength and self-reliance they often fail to close the gender gap in access to human and natural capital [8]. Consequently women are still faced as subordinate to men, a parameter that eliminates their opportunities for their incorporation in the public sphere [9]. The important role of Indonesian NGOs in the country has been widely recognized not only in promoting wider democracy and adherence to human rights. But also in development, empowerment and improvement of livelihoods [10].

According to Archibughi it is difficult to imagine national democracy without a network of democratic institutions, associations and movements at the local level. Therefore, local community relationships are needed. Gandal and Finn state that in developing countries democratic education is often considered taken for granted or ignored [11]. For that education democracy is done in two things, namely school-based democracy education is education-based democracy education and society-based democracy education is community-based education. Because it fits in the constitution law 1945 Chapter 28 (3) "everyone is entitled to freedom of association, assembly and expression". So the voice of women is also important in improving the development in the rural.

From the research result of Tremblay democracy is a complex, heterogeneus and multifaceted phenomenon. The results drawn from the analyses carried out as part of this research illustrate this, there is no homogenous and consistent set of variables that can explain, as if by magic, the proportion of women in parliaments [12]. Rather these factors very according to the context in which they are found and notably according to the length of the democratic experiment. The rural is a territorial unity or territory that is attached to and bound to human life along with the traditions and customs that move that life. The rural as a self-governing community is able to regulate itself in its own unique way. Thus such a capacity that varies between rural is the door to a more massive democratization process. The Rural Law explains that democracy is a system of organizing rural communities in a system of government undertaken by rural communities or with the consent of the rural community and the dignity of human dignity and dignity as creatures of the one and only God are recognized, organized and guaranteed. Principles of democracy in the rural that is the interests of the rural community, discussion, participation, voluntary, tolerance, humanitarian or humanist, gender justice, transparent and accountable.

\section{METHOD}

This research is based on both primary resources and secondary resourcer. The primary data is obtained through semi structured question whereas and the secondary data is obtained through extensive literature review. This research used methodology in the primary research to achieve the defined aim is qualitative data collection method that comprises of semi-structured questions which are used while interviewing members of PEKKA randomly selected. The 
question of the interview are categorized into two sections : Semi-structured method was considered as the most appropriate method for tracing democracy of education for women in rural area. A random sample of 9 members from PEKKA in Larangan area.

\section{RESULT AND DISCUSSION}

The rural of Larangan is located in the District of Larangan in Brebes district, Central Java. PEKKA Brebes was formed in 2010 and has a PEKKA center in the Larangan village. The results of research conducted by researchers at the time of the interview showed that nine PEKKA women in the rural of Larangan felt the benefits of accepted democratic education. Four of the five PEKKA women have the final education level is elementary school. To that end, the level of education does not affect the

Accepted democratic education is conducted through a critical awareness-raising education concerning law and justice for the community, advocating for the government for mobile legal services, prodeo and integrated for mobile communities, conducting critical awareness education on political rights and obligations as citizens, developing leadership potentials of PEKKA cadres to engage in decision-making processes within the community, and to facilitate the active participation of PEKKA cadres in the political process in Indonesia.

\section{A. Confidence in Opinion}

Confidence grows in someone who has courage. There are some traits of self-confident people who believe in their own ability, act independently in making decisions, have a positive sense of self and dare express opinions [13]. PEKKA focuses not only on single parent women but also on women who have husbands but unemployed husbands and single women who are the backbone of the family. PEKKA gives opportunity to its members in the rural of Larangan to dare to speak. Women's confidence in the rural of Larangan in opinion can be shown from the results of the interview below.

"In PEKKA Brebes society once a week, every member and board is given an opportunity to speak. Starting from opening the society by praying and giving the opening words. So we learn to be brave in speaking in front of others."

(Maryani, interview, February 2017)

"As a single parent, I am often looked down upon. So I feel less confident in communicating with people around. However, since I joined in the PEKKA organization the confidence reappeared "

(Kari, interview, February 2017)

From interviews to members of PEKKA Brebes in the Larangan village, shows that confidence can arise beginning with courage and training. The training can be shows with invites women to join organizational activities. When the activities began the leader of PEKKA Brebes give the opportunity for members who wants to speak up. The courage to express this opinion is done in a small scope first by providing input. And the members of PEKKA can speak up and try confidence when speak up about the evaluation of PEKKA program. So that PEKKA women can grow their confidence in giving opinion.

\section{B. Women's Participation in the Rural}

Socially, the democratic education provided is not only training but also builds the participation of PEKKA members for the community in the rural of Larangan.

"The process of participation of women in voicing their wishes in the prohibition rural is very well appreciated. One of them was when we participated in helping the community in the rural of Prohibition on understanding gender equality. Many still do not understand that women have the same rights as men"

(Wikdiniharti, interview, February 2017)

"I feel very useful to the local people when I can participate actively in the activities of the rural hall which is the seventeenth of August. Usually women are not invited in deliberation. However, since PEKKA is present in the midst of women's society can participate"

(Komariah, interview, February 2017)

PEKKA Brebes women provide opportunities for women in Larangan village to participate actively in the health area, social area, education area and politics area. Such as participation in social area, members of PEKKA with village government to share people in Larangan about how to creating identities such as family card, identity card and Birth Certificate.

"The participation of women in voicing their wishes in the rural prohibition sometimes less heard such as the filing of clean sanitation. So PEKKA Brebes makes regular social gathering to help people make clean toilet"

(Jolekha, interview, February 2017)

"In the political area, members of PEKKA learned to know about election. And we should vote and our vote is important to the village of Larangan"

(Her, interview, February 2017)

"From demoracy of education I got Democracy mandates equality of access and full participation for both men and women, on the basis of the principle of equality in all areas and levels of public life, especially in decision-making positions."

(Ay, interview, February 2017)

The results of the above interviews also indicate that the movement of rural women to participate actively required facilitators and space to train the ability of rural women to communicate in order to convey their aspirations appropriately. From the interview, PEKKA women's give the influence women in the democratic process in the prohibition rural such as in the general election of regional head in Larangan. The women's have facilitation from PEKKA to active in political with PEKKA cadres in PEKKA Brebes. And provide education 
on political rights and obligations as citizens to reduce black campaign and use the right vote very well.

\section{Critical Awareness of Rural Women}

Democracy of education in PEKKA Brebes also trains critical awareness of women in the Larangan village by meeting weekly on different topics. The topic raises the political issues as well as the problems that exist in the rural. So PEKKA Brebes women are trained to think critically in finding a way out to help rural and community leaders.

"I learned about Critical awareness of women in rural prohibition through discussion on political rights and obligations as citizens."

(Suminah, interview, February 2017)

"The education of democracy given by PEKKA to women in the rural of Larangan is also conducted with training on leadership. The background no longer makes me feel inferior. Rather I am very happy to accept the science "

(Kartini, interview, February 2017)

"Age does not become a barrier to follow education. With the current study of reading and writing I can understand democracy and increase critical awareness of the social problems that exist in the rural of Larangan by training from PEKKA"

(Sulastri, interview, February 2017)

The voice of women in the prohibition of influential ruralrs in democratic parties such as the Bupati election. The democratic education given by PEKKA enables me to have the courage to ask the vision and mission related to women. Interviews show that educational background and age are not obstacles for women have critical awareness so as to grow empathy to jointly build the rural.

\section{Control of Rural Women in Decision Making}

Governance in the rural area needs to be controlled to be evaluated when the decision is not in accordance with the community. To exercise control over rural level decisionmaking, PEKKA first provides Structured Education or Training or Paradigms in which there is also education on democracy. This paradigta is done to build the rural and sovereign.

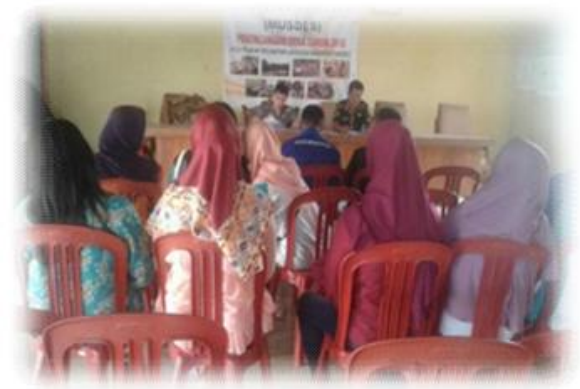

Fig. 1. The Women from PEKKA Brebes following discussion with government in Larangan area
The picture show that PEKKA women can give the critical awereness to regional governern. They the suggestion to make regulation to develop their village and critical the regulation if it has a problem or unjustice to people in Larangan.

"The paradigm academy gives me a lesson on politically empowered women's ways. So that new knowledge to be a source of inspiration "

(Maryani, interview, February 2017)

"In the academy my paradigta and other members are given the opportunity to discuss with officials in the rural one of which Istikomah Ibu who became Head of Kesambi Village in Tegal Regency. So we learned that women have a big influence in democracy. "

(Jolekha, interview, February 2017)

From the above interviews, Democracy Education can be done through academy paradigta to develop PEKKA cadres leadership potential to be involved in decision making process in society. So the existence of women in rural areas has an effect on rural progress. The Paradigta Academy also facilitates the active participation of PEKKA cadres in the political process in Indonesia.

\section{E. Balancing Citizens Rights}

As citizens of Indonesia, both men and women have the same rights and obligations. So the voice of women becomes important in realizing a democratic country.

"As a women often faces injustice in voting in the election. Ever since I joined PEKKA, one vote has been important for change and progress in the rural. "

(Suminah, interview, February 2017)

According to Sulastri is the one of PEKKA Members PEKKA has a good goal such as leadership training. The science can be used for my own good, children and others who need. Training on Political Understanding made Sulastri to understand what a good voter is like. Then selected people also know what to look like. After training Political Understanding Sulastri realizes that she also mean family leader because my husband is gone. And the existence of a leadership program made me realize that it is important to lead yourself well. And lead the group well what it looks like. So that both women and men share equality as citizens and have equal justice in the eyes of law and society.

Finally, this study shows that the theory of the important role of Indonesian NGOs in the country has been widely recognized not only in promoting wider democracy and adherence to human rights. But also in development, empowerment and improvement of livelihoods in accordance with the activities that PEKKA did in the Larangan village [10]. Democracy Education, it is not only promoting wider democracy and adherence to human rights but also empowering women to develop the rural. One of them is with active participation in elections, social control and giving opinions to build the rural for the better. And this democratic education is also in accordance with Democratic education 
helps to achieve the stated goals [14]. So that democracy is able to balancing citizens' rights in the community and working together to develop the rural. In the study of Chrysanthi Charatsari and Afroditi In general the story of her data indicate the progress of women's position within family and society was slow an erratic whereas it is still underway since gender role appropriateness remains a robust construction [6]. However, this study shows that women have the same position in social construction.

\section{CONCLUSION}

The findings of research on strengthening democracy for women in rural encourage rural women to increase their confidence in opinion. The study also provides data that the benefits of from PEKKA Prohibition provide their opportunity to participate in the community. The data collected indicate that with the activities of associations, academies paradigas and discussions have an impact on rural women to develop critical awareness, control in decision-making and balancing citizen rights. The implications of this democratic education can be developed through activities that can be further research projects to collaborate with NGOs or other local governments to obtain rural women's data in other areas. Mixed research designs include primary and secondary research combined to conclude the results. The main research is based on qualitative methods; Qualitative method used for this research is semi structured interview. A random sample of PEKKA members was selected for the interview. Interviews show that Age, educational background and residence do not affect women in the rural in understanding democratic education. However, rural women can contribute to the development of rurals with cooperation between PEKKA and women of the rural of Larangan.

\section{REFERENCES}

[1] I. Daskalopoulou, "Satisfactiob with democracy and social capital in Greece," International Journal of Social Economics, vol. 45, No. 4, pp.614-628, 2017.

[2] M. Clarke, "Organizational democracy, ethics and leadership: The mediating role of organizational politics," Leadership, vol. 7, No. 4, pp. 415-433, 2017.

[3] Prorep, Menyemarakkan Demokrasi Desa, Yayasan Satu Karsa Karya, 2015.

[4] N. Gamisonia, Challenges and Opportunities for Equal Participation of Women and Girls in Rural, 2017.

[5] A. Bishaw, "The Impact of education on rural womens participant in political and economic activities," International Journal of educational Administration and Policy Studies, vol. 6, No. 22, pp. 23-31, 2013.

[6] M. Alshurman, "Democratic Education and Administration," Procedia Social and Behavioral Science, vol. 176, pp. 861-869, 2015.

[7] C. Charatsari, and A. Papadaki-Klavdianou, "Great Expectations? Antecedents of Women Farmers' Willingness to Participate in Agricultural Education Programmes," Outlook on Agriculture vol. 42, No. 3, pp. 193 - 199, 2013.

[8] A.R. Quisumbing, and L. Pandolfelli, "Promising Approaches to Address the Needs of Poor Female Farmers: Resources, Constraints, and Interventions," World Development, vol. 38, No. 4, pp. 581-592.

[9] T. Desrues, and J.M. Nieto, "The development of gender equality for Moroccan women-illusion or reality?," Journal of Gender Studies, vol. 18, No. 1, pp. 25-34, 2009.

[10] P.J. Eldridge, Non-Government Organizations and Democratic Participation in Indonesia, Kuala Lumpur: Oxford University Press, 1995.

[11] J.E. Gandal, Education for Democracy, Calabasas: CCE, 1992.

[12] M. Tremblay, "Democracy, Representation, and Women: A Comparative Analysis, "Journal Democratization, vol. 14, pp. 533-553, 2007.

[13] A. Alsa, "Hubungan antara Dukungan Sosial Orang Tua dengan Kepercayaan Diri Remaja Penyandang Cacat Fisik," Jurnal Psikologi, vol. 1, pp. 47-48, 2006.

[14] C. Charatsari, and A. Papadaki-Klavdianou, "Great Expectations? Antecedents of Women Farmers' Willingness to Participate in Agricultural Education Programmes," Outlook on Agriculture, vol. 42, No. 3, pp. $193-199,2015$. 